\title{
COENZYME Q10 FOOD SUPPLEMENT ON THE TREATMENT OF CHRONIC PERIODONTITIS IN PATIENTS WITH TYPE II DIABETES MELLITUS: A RANDOMIZED CONTROL STUDY
}

\author{
Malak Youssef Mohamed Shoukheba* and Soheir El-Sayed Mohammed El- Kholy***
}

\begin{abstract}
The ultimate goal of the present study was, to evaluate the effectiveness of Coenzyme Q10 (CoQ 10) supplementation as an adjunct to scaling and root planing in reducing gingival inflammation and periodontal tissue destruction in chronic periodontitis patients with type II diabetes mellitus (DM).

Material and Methods: Thirty patients with chronic periodontitis and type II DM were equally divided into 2 groups. Group I received scaling and root planing plus placebo capsule for 3 months and groups II received scaling and root planing and Coenzyme Q10 for 3 months. Bleeding on probing and gingival index were taken at baseline, 1,3 and 6 months' evaluation periods while probing pocket depth, clinical attachment loss at baseline, 3 and 6 months only. Gingival crevicular fluid (GCF) samples were collected for measuring matrix metalloproteinase -8 (MMP-8) in GCF at baseline, 1,3 and 6 months' evaluation periods.
\end{abstract}

Results: Statistical analyses demonstrated a significant reduction in clinical parameters from baseline to 6 months in group II (test group) as compared to their baseline value $\mathrm{P}<0.001$, while control group showed improvement in clinical parameters up to 3 months only followed by statistically insignificant increase in the mean scores of the tested parameters at 6 months as compared to baseline values $\mathrm{P}>0.05$. Intergroup comparison showed statistically significant differences between the two studied groups at all the study evaluation periods in favor to group II (test group). GCF-MMP-8 levels showed statistically significant continual reduction from baseline up to 3 months followed by slight increase at 6 months which is still below baseline value for both group $\mathrm{P}<0.001$ with statistically highly significant differences between the two groups in favor to group II (test group) which showed the highest significant reduction in the mean MMP-8 score at all the study evaluation periods $(\mathrm{P}=0.000)$.

Conclusions: from the results of the present study it is clear that dietary supplementation with CoQ 10 may provide a low-cost intervention to augment periodontal therapy. Hence, CoQ 10 as an antioxidant could be used safely as an effective adjunct to oral prophylaxis in treatment of chronic periodontitis in diabetic patients.

KEYWORDS: Antioxidants, Diabetes mellitus, Coenzyme Q10 Periodontitis

\footnotetext{
* Associate Prof. of Oral Medicine, Periodontology, Oral Diagnosis and Radiology Department, Tanta University, Egypt

** Lecturer of Oral Medicine, Periodontology, Oral Diagnosis and Radiology Department, Tanta University, Egypt.
} 


\section{INTRODUCTION}

Chronic periodontitis is periodontal tissue destruction caused by accumulation of subgingival plaque pathogens ${ }^{1}$. Pathogenic micro-organisms can induce free radicals and reactive oxygen species (ROS) such as superoxide anion radicals, hydrogen peroxide, hypochlorous acid and hydroxyl radicals, which are capable of damaging cell membranes and associated biomolecules, thus may induce collagen and periodontal cells breakdown ${ }^{2}$.

Diabetes mellitus is a metabolic disorder leading to hyperglycemia due to altered fat and protein metabolism. Diabetes causes myriad untoward effects by altering cellular microenvironment, it is an established risk factor for periodontitis, especially if glycemic control is poor. People with poorly controlled diabetes are more prone to periodontitis and alveolar bone loss ${ }^{3,4}$. Controlling diabetes (improving glycemic control) is likely to reduce the risk and severity of periodontitis ${ }^{5}$. Moreover, evidences suggested that, resolution of periodontal inflammation can improve glycemic control with reported $\mathrm{HbA}_{1 \mathrm{c}}$ reductions ${ }^{6,7}$.

Advanced glycation end products (AGEs) contribute to reactive oxygen species (ROS) generation leading to oxidative stress and cell death. The consequences of the imbalance between production and removal of ROS can lead to oxidative stress due to the accumulation of these molecules include, structural alterations of macromolecules, such as enzymatic activation or inactivation of proteins, and disturbance in cellular signal transduction pathways that may stimulate or suppress gene expression ${ }^{8}$. It is well known that, overproduction of AGEs leads to the production of matrix metalloproteinases (MMP-8), and proinflammatory cytokines from polymorphonuclear cells, mononuclear/macrophages as well as endothelial cells ${ }^{9}$.

MMPs are recognized as key effectors of periodontal tissue breakdown and bone resorption.
The most important MMPs are neutrophil MMP-8 (collagenase-2) that degrades interstitial collagen and MMP-9 (gelatinase-B) a gelatinolytical enzyme which degrades extracellular matrix proteins, including collagen type IV, a basement membrane protein $^{10,11}$. It is worthy noted that, oxidative stress has been implicated in the regulation of MMP activation. Siwik et al., ${ }^{12}$ and Zhao et al., ${ }^{13}$ showed high MMP-2 mRNA level and enzymatic activity were seen following xanthine/xanthine oxidase treatment and ionizing radiation.

Coenzyme Q10 (Co-Q10) is a member of a family of naturally occurring substances known as quinines ${ }^{14}$, one of the most significant lipid antioxidants. It prevents the generation of free radicals and modifications of proteins, lipids, and DNA ${ }^{15}$, protecting membrane phospholipids from peroxidation and oxidative cellular damage ${ }^{16}$. It is made in our bodies, within a cell organelle "the mitochondria". Adequate amounts of CoQ 10 are essential for cellular respiration and ATP production ${ }^{17}$.

A close association has been hypothesized between type II diabetes and Co-Q10 deficiency. It has been suggested that exogenous supplementation of CoQ10 could potentially reduce mitochondrial dysfunction induced by oxidative stress produced by hyperglycemia in type II DM, thus improving glycemic control $^{18}$.

Many clinical studies with oral administration of Co-Q10 to patients with periodontal disease have been conducted. The results have shown that oral administration of Co-Q10 increases the concentration of Co-Q10 in the diseased gingiva and effectively suppresses advanced periodontal diseases ${ }^{19,20}$.

Hence, an attempt has been made in the present study to assess the effects of dietary supplement of CoQ10 in nonsurgical treatment of chronic periodontitis in diabetic type II patients after phase 1 periodontal therapy. 


\section{MATERIAL AND METHODS}

\section{Study population}

This study was conducted in the period from May 2016 to November 2017. The subjects enrolled in this study were selected from the outpatient Department of Periodontology, Faculty of Dentistry, Tanta University. The study included a total of 30 type II moderately controlled diabetic patients with glycated hemoglobin values within the range of 6-8\% were selected (diagnosed at least 1 year before baseline examination) with chronic periodontitis, ( 18 female and 12 male) aged between 30-50 years, diagnosed with generalized chronic moderate periodontitis with clinical attachment level measuring 4-5 $\mathrm{mm}$ according to Armitage $1999{ }^{21}$ were included in this study. Patients were informed about the treatment procedure and a written informed consent was taken.

\section{Exclusion criteria were}

Systemic and immunologic diseases, patient who have received antibiotics or nonsteroidal anti-inflammatory drug (like ibuprofen) in past 2-3 months, patients who have received periodontal treatment in the previous 6 months, pregnant and lactating mother, smoker or patients who consumes tobacco in any form, and those who are not willing to participate in the study.

\section{Clinical study design}

Patients were randomly divided into two groups of 15 patients each. Group I (the control group) in which patients were received oral placebo capsule after scaling and root planing. The test group (group II), in which patients were given oral CoQ10 $30 \mathrm{mg}$ (MEPACO- MEDIFOOD Enshas El Raml-Sharkeia-Egypt) twice/day for 3 months' supplements after scaling and root planing.

All patients underwent full mouth two sessions of manual scaling and root planing procedure at an interval of one week followed by polishing and proper oral hygiene instructions including twice daily brushing technique with interproximal plaque control, and asked to take their respective oral supplements twice daily for three months and not to use any mouthwash.

\section{Clinical parameters}

Clinical evaluation was performed by measuring Gingival index (GI) (Loe and Silness, 1963) 22 bleeding index (BI) (Muhlemann and Son, 197123 at baseline time (pre-treatment), 1 month 3 and 6 months' post-treatment. While probing pocket depth (PPD) according to (Ramfjord, 1967) ${ }^{24}$ and clinical attachment level (CAL) according to (Ramfjord, 1967) ${ }^{24}$ were recorded at baseline, 3 and 6 months. No scaling and root planing was done at the recall visits.

\section{Collection of gingival crevicular fluid samples}

Teeth surfaces were cleaned from supra-gingival plaque, blood, debris and dried using air syringe and isolated from saliva using cotton rolls. The samples were collected using standardized sterile paper strips. Each sterile paper strip was inserted into the gingival crevice of the deepest pocket of the selected teeth, and left for 30 seconds. The strips were immediately placed in $1.8 \mathrm{ml}$ Eppendorf tube containing $300 \mu \mathrm{l}$ phosphate buffered saline solution (Roche Applied Sciences, Canada, pH 6), $0.15 \mathrm{ml}$ $\mathrm{NaCl}$ and $0.1 \%$ tween 20 as a preservative. Samples were stored at $-80^{\circ} \mathrm{C}$ until being analyzed ${ }^{25}$. The Enzyme Linked Immunosorbent Assay (ELISA) procedure was carried out using a commercially available ELISA kit for MMP-8 by an ELISA test (Quantikine R\&D Systems Inc., Minneapolis, MN, USA). GCF samples were taken at baseline time and 1, 3 and 6 months after treatment.

\section{RESULTS}

All participants completed the study without any recorded side effects. The distribution of study participants is shown in Table 1 . A total of 
30 patients consisted of 12 males and 18 females, their ages ranged between 30 and 50 years. Distribution of mean and standard deviation values of all the clinical and biochemical parameters of both groups were illustrated in tables $(2,3,4$,and 5).

Baseline values showed no significant differences between the two groups for all the studied parameters. By applying student's Paired $t$-test, results showed a highly statistically significant decrease in clinical parameters from baseline to 6 months in group II (test group) as compared to their baseline value
$\mathrm{P}<0.001$. On the other hand, control group showed improvement in clinical parameters up to 3 months only followed by statistically insignificant increase in the mean scores of the tested parameters at 6 months as compared to baseline values $\mathrm{P}>0.05$ except for BI where it shows statistically significant decrease in BI score up to 6 months' evaluation period $\mathrm{P}<0.05$. Inter group comparison showed that, there are statistically significant differences between the two studied groups at all the study evaluation periods in favor to group II (test group). Tables 2,3,4 and 5 .

TABLE (1) The age and sex among the study groups

\begin{tabular}{|c|c|c|c|}
\hline Variable & $\begin{array}{c}\text { Group I control group } \\
\text { mean } \pm \text { SD }\end{array}$ & $\begin{array}{c}\text { Group II test group } \\
\text { mean } \pm \text { SD }\end{array}$ & P-value \\
\hline Age & $41.89 \pm 5.23$ & $42.97 \pm 6.18$ & 0.512 N.S \\
\hline Sex & 8 female $\& 7$ male & 10 female $\& 5$ male & 0.355 N.S \\
\hline
\end{tabular}

Significance: $* P<0.05, * * P<0.01, * * * P<0.001 \quad$ N.S: non-significant

TABLE (2) The effect of the treatment modalities on the GI score at the study evaluation periods.

\begin{tabular}{|c|c|c|c|c|c|}
\hline Time Groups & \multicolumn{2}{|c|}{$\begin{array}{c}\text { Group I }(n=15) \text { Control group } \\
\text { mean } \pm \text { SD }\end{array}$} & \multicolumn{2}{|c|}{$\begin{array}{c}\text { Group II }(n=15) \text { Test group } \\
\text { mean } \pm \text { SD }\end{array}$} & $\mathbf{P}$ \\
\hline Baseline & $2.30 \pm 0.16$ & & $2.38 \pm 0.14$ & & $\begin{array}{l}\mathrm{T}=-0.91 \\
\mathrm{P}=0.37\end{array}$ \\
\hline 1 month & $2.00 \pm 0.10$ & $\begin{array}{l}\mathrm{t}=6.23 \\
\mathrm{P}=0.000^{* * * *}\end{array}$ & $1.34 \pm 0.23$ & $\begin{array}{l}\mathrm{t}=14.02 \\
\mathrm{P}=0.000^{* * *}\end{array}$ & $\begin{array}{l}\mathrm{T}=11.38 \\
\mathrm{P}=0.000 * * *\end{array}$ \\
\hline 3 months & $1.98 \pm 0.11$ & $\begin{array}{l}\mathrm{t}=6.40 \\
\mathrm{P}=0.000^{* * *}\end{array}$ & $1.24 \pm 0.29$ & $\begin{array}{l}\mathrm{t}=13.59 \\
\mathrm{P}=0.000^{* * *}\end{array}$ & $\begin{array}{l}\mathrm{T}=9.87 \\
\mathrm{P}=0.000 * * *\end{array}$ \\
\hline 6 months & $2.26 \pm 0.28$ & $\begin{array}{l}\mathrm{t}=0.419 \\
\mathrm{P}=0.68 \mathrm{NS}\end{array}$ & $1.57 \pm 0.06$ & $\begin{array}{l}\mathrm{t}=14.28 \\
\mathrm{P}=0.000 * * *\end{array}$ & $\begin{array}{l}\mathrm{T}=7.46 \\
\mathrm{P}=0.000 * * *\end{array}$ \\
\hline
\end{tabular}

Significance: $* P<0.05, * * P<0.01, * * * P<0.001$ 
TABLE (3) Effect of treatment modalities on the BI score at the study evaluation periods

\begin{tabular}{|c|c|c|c|c|c|}
\hline Time $\quad$ Groups & \multicolumn{2}{|c|}{$\begin{array}{c}\text { Group I }(n=15) \text { Control group } \\
\text { mean } \pm \text { SD }\end{array}$} & \multicolumn{2}{|c|}{$\begin{array}{c}\text { Group II }(n=15) \text { Test group } \\
\text { mean } \pm \text { SD }\end{array}$} & $\mathrm{P}$ \\
\hline Baseline & $2.36 \pm 0.18$ & & $2.43 \pm 0.09$ & & $\begin{array}{l}\mathrm{I}=-0.84 \\
\mathrm{P}=0.40 \mathrm{~N} \mathrm{~S}\end{array}$ \\
\hline 1 month & $1.89 \pm 0.25$ & $\begin{array}{l}\mathrm{t}=7.51 \\
\mathrm{P}=0.000^{* * *}\end{array}$ & $1.25 \pm 0.18$ & $\begin{array}{l}\mathrm{t}=22.76 \\
\mathrm{P}=0.000^{* * * *}\end{array}$ & $\begin{array}{l}\mathrm{T}=6.28 \\
\mathrm{P}=0.000 * * *\end{array}$ \\
\hline 3 months & $2.07 \pm 0.37$ & $\begin{array}{l}\mathrm{t}=2.32 \\
\mathrm{P}=0.03^{* *}\end{array}$ & $1.14 \pm 0.14$ & $\begin{array}{l}\mathrm{t}=30.84 \\
\mathrm{P}=0.000^{* * * *}\end{array}$ & $\begin{array}{l}\mathrm{T}=7.06 \\
\mathrm{P}=0.000 * * *\end{array}$ \\
\hline 6 months & $2.56 \pm 0.15$ & $\begin{array}{l}\mathrm{t}=-2.48 \\
\mathrm{P}=0.03^{* *}\end{array}$ & $1.71 \pm 0.25$ & $\begin{array}{l}\mathrm{t}=9.93 \\
\mathrm{P}=0.000 * * *\end{array}$ & $\begin{array}{l}\mathrm{T}=9.58 \\
\mathrm{P}=0.000 * * *\end{array}$ \\
\hline
\end{tabular}

Significance: $* P<0.05, \quad * * P<0.01, \quad * * * P<0.001 \quad$ N.S : non-significant

TABLE (4) The effect of treatment modalities on the PPD score at the study evaluation periods

\begin{tabular}{|c|c|c|c|c|c|}
\hline Time - Groups & \multicolumn{2}{|c|}{$\begin{array}{c}\text { Group I }(n=15) \text { Control group } \\
\text { Mean } \pm \text { SD }\end{array}$} & \multicolumn{2}{|c|}{$\begin{array}{c}\text { Group II }(n=15) \text { Test group } \\
\text { Mean } \pm \text { SD }\end{array}$} & $\mathrm{P}$ \\
\hline Baseline & $5.46 \pm 0.74$ & & $5.66 \pm 0.72$ & & $\begin{array}{l}\mathrm{T}=-0.53 \\
\mathrm{P}=0.60 \mathrm{NS}\end{array}$ \\
\hline 3 months & $4.66 \pm 0.61$ & $\begin{array}{l}\mathrm{t}=2.86 \\
\mathrm{P}=0.01^{* *}\end{array}$ & $3.66 \pm 0.48$ & $\begin{array}{l}\mathrm{t}=8.36 \\
\mathrm{P}=0.000^{* * *}\end{array}$ & $\begin{array}{l}\mathrm{T}=4.74 \\
\mathrm{P}=0.000 * * *\end{array}$ \\
\hline 6 months & $5.06 \pm 0.59$ & $\begin{array}{l}\mathrm{t}=1.38 \\
\mathrm{P}=0.189 \mathrm{NS}\end{array}$ & $4.46 \pm 0.63$ & $\begin{array}{l}\mathrm{t}=5.39 \\
\mathrm{P}=0.000 * * *\end{array}$ & $\begin{array}{l}\mathrm{T}=2.84 \\
\mathrm{P}=0.008 * *\end{array}$ \\
\hline
\end{tabular}

Significance: $* P<0.05, \quad * * P<0.01, \quad * * * P<0.001 \quad$ N.S $:$ non-significant

TABLE (5) The effect of treatment modalities on the CAL at the study evaluation period

\begin{tabular}{|c|c|c|c|c|c|}
\hline Time Groups & \multicolumn{2}{|c|}{$\begin{array}{c}\text { Group I }(n=15) \text { Control group } \\
\text { mean } \pm \text { SD }\end{array}$} & \multicolumn{2}{|c|}{$\begin{array}{c}\text { Group II }(n=15) \text { Test group } \\
\text { mean } \pm \text { SD }\end{array}$} & $\mathrm{P}$ \\
\hline Baseline & $4.53 \pm 0.51$ & & $4.33 \pm 0.48$ & & $\begin{array}{l}\mathrm{T}=0.76 \\
\mathrm{P}=0.44 \mathrm{NS}\end{array}$ \\
\hline 3 months & $3.73 \pm 0.45$ & $\begin{array}{l}\mathrm{t}=5.52 \\
\mathrm{P}=0.000^{* * *}\end{array}$ & $3.13 \pm 0.35$ & $\begin{array}{l}\mathrm{t}=6.87 \\
\mathrm{P}=0.000^{* * * *}\end{array}$ & $\begin{array}{l}\mathrm{T}=3.47 \\
\mathrm{P}=0.002 * *\end{array}$ \\
\hline 6 months & $4.66 \pm 0.48$ & $\begin{array}{l}\mathrm{t}=-0.69 \\
\mathrm{P}=0.499 \mathrm{NS}\end{array}$ & $3.93 \pm 0.25$ & $\begin{array}{l}\mathrm{t}=3.05 \\
\mathrm{P}=0.009 * *\end{array}$ & $\begin{array}{l}\mathrm{T}=3.33 \\
\mathrm{P}=0.002 * *\end{array}$ \\
\hline
\end{tabular}

Significance: $* P<0.05, * * P<0.01, * * * P<0.001$

N.S : non-significant 
Besides the clinical parameters the effect of the treatment on GCF- MMP-8 was also evaluated at all the study evaluation periods as shown in table 6. Test group (group II) showed that, there is statistically significant continual reduction in the mean score of MMP-8 from baseline up to 3 months $(1.93 \pm 0.32)$ followed by slight increase in the mean score of MMP-8 at 6 months $(2.09 \pm 0.47)$ which is still below baseline value and statistically significant reduction as compared to baseline value $(6.25 \pm 0.42)(\mathrm{P}<0.001)$.

While in control group (Group I) there is statistically significant reduction of mean MMP8 level up to 3 months (3.94 \pm 0.73 ) followed by increase in the mean MMP-8 score (5.16 \pm 0.64$)$ that was still statistically significant as compared to baseline value $(6.45 \pm 0.43)(\mathrm{P}<0.001)$.

Inter group comparison showed that, there are statistically highly significant differences between the two treatment groups in favor to group II (test group) that showed the highest significant reduction in the mean MMP-8 score at all the study evaluation periods $(\mathrm{P}=0.03,0.000,0,000)$ respectively.

\section{DISCUSSION}

With the increased understanding of periodontal disease, it is now accepted that, the primary etiology of periodontal disease is not only bacterial but also the host inflammatory response plays a critical determinant in the pathogenesis of periodontitis ${ }^{26}$

Prolongedhyperglycemiainducesoverproduction of reactive oxygen species (ROS) from the electron transport chain in the mitochondria. Excessive generation of ROS and decreased protective mechanisms from endogenously produced antioxidants can increase oxidative stress, causing oxidative damage to deoxyribonucleic acid (DNA), proteins, and lipids ${ }^{27}$.

It has been reported that, exogenous supplementation of CoQ10 could potentially prevent mitochondrial dysfunction induced by oxidative stress, that is why improving glycemic control in type II DM ${ }^{19}$. Moreover, people with type 2 diabetes were found to have significantly lower blood levels of CoQ10 as compared with non-diabetic people ${ }^{28}$. Hence, the purpose of this study was to evaluate the effect of dietary supplementation of CoQ10 as an adjunctive therapy in diabetic patient that showed

TABLE (6) The effect of different treatment modalities on the GCF level of MMP-8 at all the study evaluation periods

\begin{tabular}{|c|c|c|c|c|c|}
\hline Time Groups & \multicolumn{2}{|c|}{$\begin{array}{c}\text { Group I }(n=15) \text { Control group } \\
\text { mean } \pm \text { SD }\end{array}$} & \multicolumn{2}{|c|}{$\begin{array}{c}\text { Group II }(\mathrm{n}=15) \text { Test group } \\
\text { mean } \pm \text { SD }\end{array}$} & $\mathrm{P}$ \\
\hline Baseline & $6.45 \pm 0.43$ & & $6.25 \pm 0.42$ & & $\begin{array}{l}\mathrm{T}=-1.27 \\
\mathrm{P}=0.21 \mathrm{NS}\end{array}$ \\
\hline 1 month & $3.71 \pm 0.44$ & $\begin{array}{l}\mathrm{t}=23.03 \\
\mathrm{P}=0.000 * * *\end{array}$ & $3.35 \pm 0.40$ & $\begin{array}{l}\mathrm{t}=19.66 \\
\mathrm{P}=0.000^{* * * *}\end{array}$ & $\begin{array}{l}\mathrm{T}=2.36 \\
\mathrm{P}=0.03^{*}\end{array}$ \\
\hline 3 months & $3.94 \pm 0.73$ & $\begin{array}{l}\mathrm{t}=10.76 \\
\mathrm{P}=0.000 * * *\end{array}$ & $1.93 \pm 0.32$ & $\begin{array}{l}\mathrm{t}=27.47 \\
\mathrm{P}=0.000^{* * *}\end{array}$ & $\begin{array}{l}\mathrm{T}=9.74 \\
\mathrm{P}=0.000 * * *\end{array}$ \\
\hline 6 months & $5.16 \pm 0.64$ & $\begin{array}{l}\mathrm{t}=6.64 \\
\mathrm{P}=0.000 * * *\end{array}$ & $2.09 \pm 0.47$ & $\begin{array}{l}\mathrm{t}=21.45 \\
\mathrm{P}=0.000 * * *\end{array}$ & $\begin{array}{l}\mathrm{T}=14.58 \\
\mathrm{P}=0.000 * * *\end{array}$ \\
\hline
\end{tabular}

Significance: $* P<0.05, \quad * * P<0.01, \quad * * * P<0.001 \quad$ N.S $:$ non-significant 
periodontal destruction.

In the present study standard scaling and root planing and oral hygiene measures were performed in the two groups to eliminated or at least minimized the pathogenic burden to the gingival and periodontal tissues.

Both test and control groups showed statistically significant reduction in clinical parameters with more significant reduction to the test group than control group. The reduction in clinical parameters could be related to SRP and oral hygiene instruction given to the patients, and the more significant reduction shown in the test group could be related to the anti- inflammatory action of coenzyme Q10 and its synergistic effect to SRP caused by the antioxidant effect of CoQ10 that minimized tissue destruction by removal of free radicals ${ }^{29}$. Moreover, CoQ10 as an antioxidant may play a role in reducing collagenous destruction ${ }^{15}$.

Many studies suggested that, deficiency of Co Q10 might have an adverse effect on glucose tolerance as proved by decreased levels of Co Q10 in rats with-induced diabetes ${ }^{30,31}$. Moreover, administration of Co Q7 (the analog of Co Q10) partially corrected altered glucose metabolism in alloxan-diabetic rats ${ }^{32}$. Hence diabetic patients receiving combined coenzyme Q10 therapy and oral prophylaxis, significantly reduced PPD, CAL, BI and GI.

Furthermore, Hanioka et al., ${ }^{33}$ evaluated the effect of subgingival debridement with topical application of Co Q10 to periodontal pockets. They noticed that, sites received Co Q10 topical application after subgingival debridement showed significant improvements in gingival index and bleeding on probing when compared to sites that received only subgingival debridement.

Additionally, Matsumura et al. ${ }^{34}$ in their doubleblind trial, they reported that, oral hygiene combined with Co Q10 supplement could provide improved treatment and long-term benefits for patients with periodontitis.
Many studies have suggested that, Co Q10 exerts anti-inflammatory properties via nuclear factorkappa B (NF $x$ B1)-dependent gene expression and this is might be the possible mechanism for reduction in gingival inflammation after Co Q10 supplementation $^{35,36}$.

This can be explained by that, Co Q10 has favorable effect on the endothelial cells of the blood vessels and partial bacteriostatic effect on subgingival microorganisms ${ }^{37}$. In addition, it increases the phagocytic activity of macrophages, proliferation of granulocytes in response to infections, and improves oxygen utilization in the gingival cells ${ }^{38}$.

Since MMP-8 is a key enzyme in extracellular collagen matrix degradation derived predominantly from PMNs during acute periodontal inflammation, ${ }^{39}$ and is also strongly associated with progressive periodontitis, its inhibition therefore could restore the balance between collagen degradation and deposition thereby arresting periodontal breakdown ${ }^{40}$.

The current investigation also revealed the effect of Co Q10 on the modulation of GCF MMP-8 activity showing a significant reduction in MMP8. This reduction in GCF- MMP-8 biomarkers correlated well with clinical improvement after SRP, but their reduction was enhanced by dietary supplementation with Co Q10. The results seem to suggest that Co Q10 can be used as an adjunct to oral prophylaxis in control of periodontal diseases in diabetic patients. This inhibition of MMP-8 could be attributed to the potent antioxidant effect of Co Q10 as MMP-8 levels are influenced by oxidative stress where ROS regulate MMP-8 gene expression and activation ${ }^{41}$. In conclusion, regulation of MMP8 activity is an additional mechanism of Co Q10 in the treatment or inhibition of periodontal breakdown in diabetic patients.

Hence, within the limitations of this study that includes small sample size in total and short time of follow up, it can be concluded that, antioxidants could be used as an effective adjunct to oral prophylaxis. Further evaluate long-term effects of antioxidant therapy on periodontal inflammation are required. 


\section{REFERENCES}

1- Page RC, Kornman KS. The pathogenesis of human periodontitis: an introduction. Periodontol 2000. 1997; 14:9-11.

2- Battino M, Bullon P, Wilson M, Newman H. Oxidative injury and inflammatory periodontal diseases: the challenge of anti-oxidants to free radicals and reactive oxygen species. Crit Rev Oral Biol Med. 1999;10:458-76.

3- Pucher J, Stewart J. Periodontal disease and diabetes mellitus. Curr Diab Rep. 2004; 4:46-50.

4. Joshi SR, Parikh RM. India-Diabetes capital of the world: Now heading towards hypertension. J Assoc Physicians India. 2007;55:323-324.

5- Nagasawa T, Noda M, Katagiri S, Takaichi M, Takahashi Y, Wara-Aswapati $\mathrm{N}$ et al. Relationship between periodontitis and diabetes - importance of a clinical study to prove the vicious cycle. Intern Med. 2010; 49: 881-885.

6- Chen L, Luo G, Xuan D, Wei B, Liu F, Li J, Zhang J.. Effects of non-surgical periodontal treatment on clinical response, serum inflammatory parameters, and metabolic controlin patients with type 2 diabetes: a randomized study. J Periodontol. 2012; 83:435-443.

7- Chapple IL, Genco R. Working group 2 of joint EFP/AAP workshop. Diabetes and periodontal diseases: consensus report of the Joint EFP/ AAP Workshop on Periodontitis and Systemic Diseases. J Clin Periodontol. 2013;40(Suppl 14):S106-S112.

8- Nowotny K, Jung T, Höhn A, Weber D, Grune T: Advanced Glycation End Products and Oxidative Stress in Type 2 Diabetes Mellitus. Biomolecules. 2015; 5: 194-222.

9- Schmidt AM, Weidman E, Lalla E, Yan SD, Hori O, Cao $\mathrm{R}$, et al. Advanced glycation endproducts (AGEs) induce oxidant stress In the gingiva: a potential mechanism underlying accelerated periodontal disease associated with diabetes. J Periodontal Res. 1996; 31:508-15.

10- Buzoglu H, Unal H, Ulger C, Mert S, Kucukyildirim S, Er N. The zymographic evaluation of gelatinase (MMP-2 and -9) levels in acute and chronic periapical abscesses. Oral Surg Oral Med Oral Pathol Oral Radiol Endod. 2009 ; 108 :121-126.

11- de Paula-Silva F, D'Silva N, da Silva L, Kapila Y. High matrix metalloproteinase activity is a hallmark of periapical granulomas. J Endod. 2009; 35:1234-1242.
12- Siwik D A, Pagano P.J, Colucci W S. Oxidative stress regulates collagen synthesis and matrix metalloproteinase activity in cardiac fibroblasts. Am. J. Physiol. 2001; 280: 53-60.

13- Zhao W, O’Malley YQ, Wei S, Robbins ME. Irradiation of rat tubule epithelial cells alters the expression of gene products associated with the synthesis and degradation of extracellular matrix. Int. J. Radiat. Biol. 2000; 76:391402.

14- Saini R. Coenzyme Q10: The essential nutrient. J Pharm Bioallied Sci. 2011;3: 466-467.

15- Saini R. Vitamins and periodontitis. J Pharm Bioallied Sci. 2011; 3:170.

16- Battino M, Ferreiro MS, Bompadre S, Leone L, Mosca F, Bullon P. Elevated hydroperoxide levels and antioxidant patterns in Papillon-Lefèvre syndrome. J Periodontol. 2001;72:1760-1766.

17- Saini R. A clinical and microbiological study to evaluate the effect of dietary supplement of coenzyme Q10 in nonsurgical treatment outcome of chronic periodontitis patients after phase 1 periodontal therapy. European J General Dentistry. 2014; 3:194-198.

18- Alam, MA, Rahman, MM. Mitochondrial dysfunction in obesity: Potential benefit and mechanism of co-enzyme Q10 supplementation in metabolic syndrome. J. Diabetes Metab. Disord. 2014, 13, 60.

19- Wilkinson EG. Bioenergetics in clinical medicine. II. Adjunctive treatment with coenzyme $\mathrm{Q}$ in periodontal treatment. Res Commun Chemic Path Pharm. 1975; 12:111-124.

20- McRee JT, Hanioka T, Shizukuishi S, Folkers K. Therapy with Coenzyme Q10 for patients with periodontal disease. 1. Effect of Coenzyme Q10 on subgingival microorganisms. J Dent Health. 1993; 43:659-66.

21- Armitage G C. Development of a classification system for periodontal diseases and conditions. Annals of Periodontology. 1999 ; 4: 1-6.

22- H. Loe, J. SilnessPeriodontal disease in pregnancy I. Prevalence and severity. Acta Odontol Scand, 1963; 21:533-551.

23- Mühlemann HR, Son S. Gingival sulcus bleeding--a leading symptom in initial gingivitis. Helv Odontol Acta. 1971;15:107-113.

24- S.P. RamfjordThe periodontal disease index (PDI). J Periodontol,1967; 6: 602-610. 
25- Avellan NL, Sorsa T, Tervahartiala T, Mäntylä P, Forster C, Kemppainen P. Painful tooth stimulation elevates matrix metalloproteinase- 8 levels locally in human gingival crevicular fluid. J Dent Res. 2005;84: 335-339.

26- Soorya K V, Suchetha A, Lakshmi P, Sapna N, Apoorva SM, Divya Bhat.The Effect of Scaling and Root Planing on Glycaemic Control, Periodontal Status and Gingival Crevicular Fluid TNF- $\alpha$ Levels in an Indian Population- To Reveal the Ambivalent Link. J Clin Diagn Res. 2014 ; 811: 22-26.

27- Soskolne WA, Klinger A. The relationship between periodontal diseases and diabetes: an overview. Ann Periodontol. 2001;6:91-98.

28- Miyake Y, Shouzu A, Nishikawa M, Yonemoto T, Shimizu H, Omoto S. Effect of treatment with 3-hydroxy-3-methylglutaryl coenzyme A reductase inhibitors on serum coenzyme $\mathrm{Q}_{10}$ in diabetic patients. Arzneimittelforschung. 1999; 49:324-329.

29- Prakash S, Sunitha J, Hans M. Role of coenzyme Q(10) as an antioxidant and bioenergizer in periodontal diseases. Indian J Pharmacol. 2010;42: 334-337.

30- Alan R, Gaby MD. The Role of Coenzyme Q10 in Clinical Medicine: Part II. Cardiovascular Disease, Hypertension, Diabetes Mellitus and Infertility. Alt Med Rev. 1996;1:168-175.

31- Prangthip P, Kettawan A, Posuwan J, Okuno M, Okamoto T. An Improvement of Oxidative Stress in Diabetic Rats by Ubiquinone-10 and Ubiquinol-10 and Bioavailability after Short- and Long-Term Coenzyme Q10 Supplementation. J Diet Suppl. 2016;13:647-59.

32- Ketan P, Santosh L, Ramesh K, Parloop A. Beneficial Effects of Coenzyme Q10 in Streptozotocin-Induced Type I Diabetic Rats. IJPT, 2006; 5:61-65.

33- Hanioka T, Tanaka M, Ojima M, Shizukuishi S, Folkers K. Effect of topical application of coenzyme Q10 on adult periodontitis. Mol Aspects Med. 1994;15: 241-48.

34- Matsumura T, Saji S, Nakamura R, Folkers K. Evidence for enhanced treatment of periodontal disease by therapy with coenzyme Q. Int J Vitam Nutr Res. 1973;43:537-48.

35- Schmelzer C, Lindner I, Rimbach G, Niklowitz P, Menke $\mathrm{T}$, Doring F. Functions of coenzyme Q 10 in inflammation and gene expression. Biofactors. 2008;32:179-83.

36- Zhai J, Bo Y, Lu Y, Liu C, Zhang L. Effects of Coenzyme Q10 on Markers of Inflammation: A Systematic Review and Meta-Analysis. PLoS One. 2017 ;12:1-11.

37- Kaikkonen J, Nyyssönen K, Porkkala-Sarataho E, Poulsen HE, Metsä-Ketelä T, Hayn M, et al. Effect of oral coenzyme Q10 supplementation on the oxidation resistance of human VLDL+LDL fraction: absorption and antioxidative properties of oil and granule-based preparations. Free Radic Biol Med. 1997; 22: 1195-1202.

38- Tüter G, Serdar M, Kurtis B, Walker S, Atak A, Toyman U, et al. Effects of scaling and root planing and subantimicrobial dose doxycycline on gingival crevicular fluid levels of matrix metalloproteinase-8,-13 and serum levels of HsCRP in patients with chronic periodontitis. J Periodontol. 2010;81: 1132-1139.

39- Caton JG, Ciancio SG, Blieden TM, Bradshaw M, Crout RJ, Hefti AF, et al. Subantimicrobial dose doxycycline as an adjunct to scaling and root planing: post-treatment effects. J. Clin. Periodontol. 2001;8:782-789.

40- Novak MJ, Johns LP, Miller RC, Bradshaw MH. Adjunctive benefits of subantimicrobial dose doxycycline in the management of severe, generalized, chronic periodontitis. J. Periodontol. 2002;73:762-769.

41- Lu Y, Wahl ML: Oxidative Stress Augments the Production of Matrix Metalloproteinase-1, Cyclooxygenase-2, and Prostaglandin $\mathrm{E}_{2}$ through Enhancement of NF- $x \mathrm{~B}$ Activity in Lipopolysaccharide-Activated Human Primary Monocytes. J Immunol . 2005, 175 : 5423-5429; 